\title{
OVERVIEW OF PREGNANT WOMAN BEHAVIOUR AGAINST ANTE- NATAL CARE COMPLIANCE IN KEBON KALAPA VILLAGE, CIS- ARUA SUB-DISTRICT, SUMEDANG REGENCY, WEST JAVA IN 2019
}

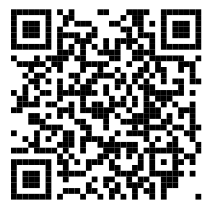

\author{
Gorga I. V. W. Udjung ${ }^{1}$ and Vidi Posdo A. Simarmata ${ }^{2}$ \\ ${ }^{1}$ Department of Obstetrics and Gynecology, Medical Faculty, Universitas Kristen, Jakarta, Indonesia \\ ${ }^{2}$ Department of Medical Community, Medical Faculty, Universitas Kristen, Jakarta, Indonesia
}

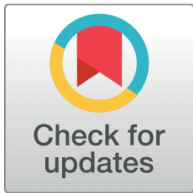

Received 6 April 2021

Accepted 21 April 2021

Published 30 April 2021

Corresponding Author

Gorga I. V. W. Udjung, gorga.udjung @uki.ac.id

DOI $10.29121 /$

granthaalayah.v9.i4.2021.3856

Funding: This research received no specific grant from any funding agency in the public, commercial, or not-for-profit sectors.

Copyright: (C) 2021 The Author(s). This is an open access article distributed under the terms of the Creative Commons Attribution License, which permits unrestricted use, distribution, and reproduction in any medium, provided the original author and source are credited.

\section{ABSTRACT}

Antenatal services, according to standards, are services provided to pregnant women, given four times during pregnancy. According to RISKESDAS Data, the province's antenatal care proportion in Indonesia was 2013 at $95.2 \%$ and 2018 at $96.1 \%$ over the past five years. This study was designed to describe pregnant women against antenatal mediation in Kebon Kalapa Village, Cisarua District, Sumedang, West Java, 2019. This research is a descriptive-analytic study. Sampling using purposive sampling technique and obtained a total sample of 22 respondents. The results showed significant differences between pregnant women's knowledge, attitudes, and practices about the regulation of antenatal care in Kebon Kalapa Village, Cisarua District, Sumedang, West Java, in 2019. The research studies showed that there was a significant difference between knowledge, attitudes and antenatal care practices in Kebon Kalapa Village, Cisarua District, Sumedang, West Java, 2019 with an overview of good knowledge is nine people (40.9\%) and sufficient knowledge of 4 people $(18.2 \%)$. An overview of a good attitude is 21 people (95.5\%), and an overview of good practice is 17 people (77.3\%). The overview of antenatal care is 18 people (81.8\%). Most pregnant women in Kebon Kalapa Village, Cisarua District, Sumedang Regency, West Java In 2019 have good knowledge, and most pregnant women in Kebon Kalapa Village, Cisarua District, Sumedang District, West Java, 2019 have a positive attitude. Most pregnant women in Kebon Kalapa Village Cisarua Sumedang Regency, West Java 2019 have positive practice, and most pregnant women in Kebon Kalapa Village, Cisarua Sub-District, Sumedang District, West Java, 2019 are obedient to antenatal care.

Keywords: Behaviour of Pregnant Women, Compliance with Antenatal Care 


\section{INTRODUCTION}

An antenatal care service provides pregnant women at least four times during their pregnancy with a one-time scheduled in the first trimester, a one-time scheduled in the second trimester and two-time scheduled in the third trimester done by a midwife or doctor or obstetrician who works at government or private health service facilities with a registration certificate Alder et al. (2007); Gaston and Cramp (2011). There was an increase in antenatal care examinations in women aged $10-54$ years in Indonesia from 2013-2018, which1was 95,2\% in 2013 and 96,1\% in 2018 Doktorchik et al. (2018); Kieffer et al. (2013). There some problem that Indonesia still faces in antenatal care services, not only from access but also the quality of services and the availability of facilities must be improved Kumbani et al. (2013); Sibiya et al. (2018); Tran et al. (2012). These are related to the ease of transportation facilities and infrastructure.Antenatal services, according to standards, are services provided to pregnant women at least four times during pregnancy with a schedule of one time in the first trimester, one time in the second trimester and two times in the third trimester conducted by midwives and doctors and midwifery specialists who work in government and private health care facilities that have a Registration Certificate Metgud et al. (2009); Oladapo et al. (2008); van Eijk et al. (2006). The health service implementation assessment for pregnant women can be done by looking at the coverage of $\mathrm{K} 1$ and $\mathrm{K} 4$. Coverage $\mathrm{K} 1$ is the number of pregnant women who have received antenatal care for the first time by health workers compared to the target number of pregnant women in one work area for one year Kamo et al. (2018); Orboi et al. (2019a, 2019b). Whereas K4 coverage is the number of pregnant women who have obtained antenatal care according to the standard at least four times according to the recommended schedule in each trimester compared to the target number of pregnant women in one work area for one year Mardahlia (2018); Prasetyo et al. (2018); Wau and Razella (2020).

In addition to the elements of action that must be met by health services for pregnant women must also meet the minimum frequency in each trimester, namely at least once in the first trimester (0-12 weeks gestation), at least once in the second trimester (12-24 weeks gestation), and at least twice in the third trimester (24 weeks' gestation until delivery) Bothwell (2000); Costa et al. (2003). The standard of service time is recommended to ensure the protection of pregnant women and the fetus in the early detection of risk factors, prevention, and early treatment of pregnancy complications Fretts (2005); Marion and Meeks (2012). Constraints faced in implementing health services for pregnant women are not only in terms of access. The quality of services provided must also be improved, including fulfilling all health care components for pregnant women should be given during the visit Feroz et al. (2017); Macinko and Harris (2015). In terms of the availability of health facilities, until December 2017, there are 9,825 health centres. The existence of a health centre should ideally be supported with reasonable accessibility Ensor (2004). It is, of course, very related to geographical aspects and the ease of transportation facilities 
and infrastructure. In supporting outreach to the community in its working area, the puskesmas has also applied the satellite concept by providing auxiliary health centres. Based on the description, the researcher was interested in examining the relationship between pregnant women's behaviour towards adherence to antenatal care in the Village of Kebon Kalapa, Cisarua Sub-District, Sumedang District West Java in 2019.

\section{METHOD}

This study uses descriptive research methods to analyze the description of knowledge, attitudes, and practices on antenatal care adherence in Kebon Kalapa Village, Cisarua Sub-district, Sumedang Regency, and West Java 2019. This study took place from 24 June 2019 - 5 July 2019. The research site was in Kebon Kalapa Village, Sumedang Regency. The population in this study were pregnant women in the 1 st trimester to the third trimester. This study's sampling method was non-random sampling with a purposive sampling method, which will take all data that met the inclusion criteria as many as 22 respondents. Inclusion criteria: Mothers who become pregnant in the 1st trimester to the third trimester and are at the research location and pregnant women in the 1st trimester to the third trimester are cooperative and willing to be respondents in the questionnaire. Exclusion Criteria: Mothers who are pregnant in the 1st to the third trimester who are unwilling to conduct interviews and fill out questionnaires and non-pregnant mothers. Data processing techniques in this study used computational calculation of the SPSS program (Statistical Product and Service Solution), consisting of data editing, data coding, data entry and manual tabulating. The sequence of activities is as follows: 1.) Data editing is done to control the quality of data that has been obtained, in the form of data on the behaviour of pregnant women and adherence to antenatal care. 2.) Coding and scoring are the activity of Coding every data obtained, then giving it a score to facilitate data analysis. 3.) Data entry is the activity of entering data into a computer program for data analysis. 4.) Tabulating is the activity of entering data into tables and measuring the numbers obtained so that the distribution and percentage can be calculated and can be analyzed. This study's analysis technique is a univariate test to see the frequency distribution of the research variables. Measure the behaviour of pregnant women and adherence to antenatal care.

\section{RESULT AND DISCUSSION}

Samples for this research are pregnant mothers in the 1st trimester to the third trimester in June 2019 in the village Kebon Kalapa, Regency Sumedang, West Java, with 22 people.

Based on the table above, obtained in part significant respondent aged 20-30 years and aged 31-40 years were 13 respondents (59.1\%), while respondent aged 


\begin{tabular}{ccc}
\hline Table 1 Age Distribution \\
\hline Age & N & \% \\
\hline 20 years old & 4 & 18.2 \\
\hline 20-30 years & 13 & 59.1 \\
\hline 31-40 years old & 5 & 22.7 \\
\hline Total & 22 & 100 \\
\hline
\end{tabular}

$31-40$ years were of 5 respondents $(22.7 \%)$, and respondents aged $<20$ years number $4(18.2 \%)$.

\begin{tabular}{ccc}
\hline Table 2 Job Distribution & & \\
\hline Work pregnant mother & $\mathrm{N}$ & $\mathbf{\%}$ \\
\hline Housewife & 18 & 81.8 \\
\hline Teacher & 1 & 4.5 \\
Midwife & 1 & 4.5 \\
\hline Labourer & 1 & 4.5 \\
\hline Civil Servants & 1 & 4.5 \\
\hline Total & 22 & 100 \\
\hline
\end{tabular}

Based on the table above, obtained in part significant respondent work as a housewife, a total of 18 people (81.8\%). While respondents who work as a teacher 1 number $(4.5 \%)$, there was one midwife $(4.5 \%)$, and one labour $(4.5 \%)$, and one civil servant $(4.5 \%)$.

\begin{tabular}{ccc}
\hline Table 3 Education Distribution & & \\
\hline Education & N & $\mathbf{\%}$ \\
\hline Graduated from elementary school & 4 & 18.2 \\
\hline Graduated from junior high school & 8 & 36.4 \\
Graduated from high school & 8 & 36.4 \\
\hline Graduate D3 / S1 / S2 & 2 & 9.1 \\
\hline Total & 22 & 100 \\
\hline
\end{tabular}

Based on the table above, obtained in part significant respondent have education graduated from junior high school with eight people (36.4\%) and graduated from high school a total of 8 people (36.4\%). Respondents who graduated from elementary school with four people (18.2\%) and respondents who owned it graduated D3/SI/S2 with two people (9.1\%).

Based on the table above, it is obtained that the larger respondent is located in age third-trimester pregnancy (24 weeks - delivery) (A total of 11 people (50, 0, \%) and second trimester (12-24 weeks) were 9 (40.9\%). Meanwhile, respondents in age pregnancy were at the first trimester (1-12 weeks) were 2 (9.1\%). 


\begin{tabular}{|ccc|}
\hline Table 4 Age ofPregnancy Distribution \\
\hline Age of Pregnancy & N & $\mathbf{\%}$ \\
\hline Trimester 1 (1-12 weeks) & 2 & 9.1 \\
\hline Trimester 2 (12-24 weeks) & 9 & 40.9 \\
\hline Trimester 3 (24 weeks of labour) & 11 & 50.0 \\
\hline Total & 22 & 100 \\
\hline
\end{tabular}

\begin{tabular}{|c|c|c|}
\hline Total Pregnancy & $\mathbf{N}$ & $\%$ \\
\hline First time & 8 & 36.4 \\
\hline Twice & 8 & 36.4 \\
\hline Three times & 4 & 18.2 \\
\hline Four times or more & 2 & 8.1 \\
\hline Total & 22 & 100 \\
\hline
\end{tabular}

Based on the table above, it is obtained that the larger respondent was in the first and second times each was eight people (36.4\%). While total pregnancy as much three times to respondents, namely four people (18.2\%) and the amount pregnancy as many four times to respondents, two people (8.1\%).

Behaviour is influenced by knowledge, attitudes, and practices Faour-Klingbeil et al. (2015); Salas-Zapata et al. (2018). Other factors, such as education, also influence behaviour. It is consistent with the research conducted by Siti Komariyah (2018), who also explained that good behaviour would result in increasingly regular pregnancy check-ups de Weerth et al. (2003); Gokyildiz et al. (2014). It is also by univariate analysis, which is obtained from the description of knowledge of pregnant women about antenatal care in the village of Kebon Kalapa, Sumedang Regency, namely pregnant women who have good knowledge of 9 people (40.9\%), pregnant women who have enough knowledge as much as four people (18.2\%), and nine pregnant women who have good knowledge (40.9\%). Besides, it was also an overview of pregnant women's attitude about antenatal care in the village of Kebon Kalapa, Sumedang Regency, which had 17 positive practices (77.3\%). For pregnant women who adhere to antenatal care, as many as 18 people (81.8\%).

\section{CONCLUSION}

Based on the results of the research "Description of Pregnant Women Behavior on Compliance with Antenatal Care in Kebon Kalapa Village, Cisarua District, Sumedang Regency, West Java in 2019" which was conducted on 22 samples, the following conclusions were obtained: a) Based on the univariate analysis of pregnant women, it can be concluded that most of the pregnant women in Kebon Kalapa Village, Cisarua 
District, Sumedang Regency, West Java In 2019, 9 people (40.9\%) had good knowledge and 4 people (18.2\%) had sufficient knowledge; b) Based on the univariate analysis of pregnant women, it can be concluded that the majority of pregnant women in Kebon Kalapa Village, Cisarua District, Sumedang Regency, West Java in 2019 had positive attitudes as many as 21 people (95.5\%); c) Based on the univariate analysis of pregnant women, it can be concluded that the majority of pregnant women in Kebon Kalapa Village, Cisarua District, Sumedang Regency, West Java in 2019 had positive practices as many as 17 people (77.3\%); and d) Based on univariate analysis, most pregnant women in Kebon Kalapa Village, Cisarua District, Sumedang Regency, West Java in 2019 obeyed antenatal care, namely 18 people (81.8\%). The description of good knowledge was nine people (40.9\%), and sufficient knowledge was four people (18.2\%). There were 21 people (95.5\%) with a positive attitude. There were 17 positive practice figures $(77.3 \%)$. The description of adherence to antenatal care was 18 people (81.8\%).

\section{REFERENCES}

Alder, J., Fink, N., Bitzer, J., Hösli, I., \& Holzgreve, W. (2007). Depression and anxiety during pregnancy: A risk factor for obstetric, fetal and neonatal outcome? A critical review of the literature. The Journal of Maternal-Fetal \& Neonatal Medicine, 20(3), 189-209. Retrieved from https://dx.doi.org/10.1080/1476705070120956010 $.1080 / 14767050701209560$

Bothwell, T. H. (2000). Iron requirements in pregnancy and strategies to meet them. The American Journal of Clinical Nutrition, 72(1), 257S-264S. Retrieved from https://dx.doi .org/10.1093/ajcn/72.1.257s 10.1093/ajcn/72.1.257s

Costa, D. D., Rippen, N., Dritsa, M., \& Ring, A. (2003). Self-reported leisure-time physical activity during pregnancy and relationship to psychological well-being. Journal of Psychosomatic Obstetrics \& Gynecology, 24(2), 111-119. Retrieved from https://dx.doi.org/ 10.3109/01674820309042808 10.3109/01674820309042808

de Weerth, C., van Hees, Y., \& Buitelaar, J. K. (2003). Prenatal maternal cortisol levels and infant behavior during the first 5 months. Early Human Development, 74(2), 139-151. Retrieved from https://dx.doi.org/10.1016/s0378-3782(03)00088-4 10.1016/s0378 -3782(03)00088-4

Doktorchik, C., Premji, S., Slater, D., Williamson, T., Tough, S., \& Patten, S. (2018). Patterns of change in anxiety and depression during pregnancy predict preterm birth. Journal of Affective Disorders, 227, 71-78. Retrieved from https://dx.doi.org/10.1016/j.jad.2017 .10 .001 10.1016/j.jad.2017.10.001

Ensor, T. (2004). Overcoming barriers to health service access: influencing the demand side (Vol. 19). Oxford University Press (OUP). Retrieved from https://dx.doi.org/10.1093/ heapol/czh009 10.1093/heapol/czh009

Faour-Klingbeil, D., Kuri, V., \& Todd, E. (2015). Investigating a link of two different types of food business management to the food safety knowledge, attitudes and practices of food handlers in Beirut, Lebanon. Food Control, 55, 166-175. Retrieved from https:// dx.doi.org/10.1016/j.foodcont.2015.02.045 10.1016/j.foodcont.2015.02.045

Feroz, A., Perveen, S., \& Aftab, W. (2017). Role of mHealth applications for improving antenatal and postnatal care in low and middle income countries: a systematic review. BMC 
Health Services Research, 17(1), 1-11. Retrieved from https://dx.doi.org/10.1186/ s12913-017-2664-7 10.1186/s12913-017-2664-7

Fretts, R. C. (2005). Etiology and prevention of stillbirth. American Journal of Obstetrics and Gynecology, 193(6), 1923-1935. Retrieved from https://dx.doi.org/10.1016/j.ajog .2005.03.074 10.1016/j.ajog.2005.03.074

Gaston, A., \& Cramp, A. (2011). Exercise during pregnancy: A review of patterns and determinants. Journal of Science and Medicine in Sport, 14(4), 299-305. Retrieved from https://dx.doi.org/10.1016/j.jsams.2011.02.006 10.1016/j.jsams.2011.02.006

Gokyildiz, S., Alan, S., Elmas, E., Bostanci, A., \& Kucuk, E. (2014). Health-promoting lifestyle behaviours in pregnant women in Turkey. International Journal of Nursing Practice, 20(4), 390-397. Retrieved from https://dx.doi.org/10.1111/ijn.12187 10.1111/ijn .12187

Kamo, B., Msen, Y., Rantetampang, A., \& Mallongi, A. (2018). Education. The factors affecting with four visited at public health centre Sub Province Mimika Papuan Province, 6-6.

Kieffer, E. C., Caldwell, C. H., Welmerink, D. B., Welch, K. B., Sinco, B. R., \& Guzmán, J. R. (2013). Effect of the healthy MOMs lifestyle intervention on reducing depressive symptoms among pregnant Latinas. American journal of community psychology, 51(1), 76-89.

Kumbani, L., Bjune, G., Chirwa, E., Malata, A., \& Odland, J. Ø. (2013). Why some women fail to give birth at health facilities: a qualitative study of women's perceptions of perinatal care from rural Southern Malawi. Reproductive Health, 10(1), 1-12. Retrieved from https://dx.doi.org/10.1186/1742-4755-10-9 10.1186/1742-4755-10-9

Macinko, J., \& Harris, M. J. (2015). Brazil's Family Health Strategy — Delivering CommunityBased Primary Care in a Universal Health System. New England Journal of Medicine, 372(23), 2177-2181. Retrieved from https://dx.doi.org/10.1056/nejmp1501140 10 .1056/nejmp1501140

Mardahlia, D. (2018). Correlation Between Distance and Time of Travel and Utilization of Antenatal Care at Community Health Center. Gundih, Surabaya. Health Notions, 2(5), 531-533.

Marion, L. L., \& Meeks, G. R. (2012). Ectopic pregnancy: history, incidence, epidemiology, and risk factors. Clinical obstetrics and gynecology, 55(2), 376-386.

Metgud, C. S., Katti, S. M., Mallapur, M. D., \& Wantamutte, A. S. (2009). Utilization patterns of antenatal services among pregnant women: a longitudinal study in rural area of north Karnataka. Al Ameen J Med Sci, 2(1), 58-62.

Oladapo, O. T., Iyaniwura, C. A., \& Sule-Odu, A. O. (2008). Quality of antenatal services at the primary care level in southwest Nigeria. African Journal of Reproductive Health, 12(3).

Orboi, Y., Msen, Y., Ruru, Y., \& Mallongi, A. (2019a). The factors influencing four visited antenatal care in primary health centre in Sanggeng Manokari district, West Papua province. International Journal of Science and Healthcare Research, 4-4.

Orboi, Y., Msen, Y., Ruru, Y., \& Mallongi, A. (2019b). The factors influencing four visited antenatal care in primary health centre in Sanggeng Manokari district, West Papua province. International Journal of Science and Healthcare Research, 4-4.

Prasetyo, B., Damayanti, H. E., Pranadyan, R., Habibie, P. H., Romdhoni, A. C., \& Islami, D. (2018). Maternal mortality audit based on district maternal health performance in East Java Province, Indonesia. Bali Medical Journal, 7(1), 61-61. Retrieved from https:// dx.doi.org/10.15562/bmj.v7i1.761 10.15562/bmj.v7i1.761

Salas-Zapata, W. A., Ríos-Osorio, L. A., \& Cardona-Arias, J. A. (2018). Knowledge, Attitudes and Practices of Sustainability: Systematic Review 1990-2016. Journal of Teacher Education for Sustainability, 20(1), 46-63. Retrieved from https://dx.doi.org/10.2478/ 
jtes-2018-0003 10.2478/jtes-2018-0003

Sibiya, M. N., Ngxongo, T. S. P., \& Bhengu, T. J. (2018). Access and utilisation of antenatal care services in a rural community of eThekwini district in KwaZulu-Natal. International Journal of Africa Nursing Sciences, 8, 1-7. Retrieved from https://dx.doi.org/10.1016/ j.ijans.2018.01.002 10.1016/j.ijans.2018.01.002

Tran, T. K., Gottvall, K., Nguyen, H. D., Ascher, H., \& Petzold, M. (2012). Factors associated with antenatal care adequacy in rural and urban contexts-results from two health and demographic surveillance sites in Vietnam. BMC Health Services Research, 12(1), 1-10. Retrieved from https://dx.doi.org/10.1186/1472-6963-12-40 10.1186/1472 $-6963-12-40$

van Eijk, A. M., Bles, H. M., Odhiambo, F., Ayisi, J. G., Blokland, I. E., Rosen, D. H., Adazu, K., Slutsker, L., \& Lindblade, K. A. (2006). Use of antenatal services and delivery care among women in rural western Kenya: a community based survey. Reproductive Health, 3(1), 1-9. Retrieved from https://dx.doi.org/10.1186/1742-4755-3-2 10.1186/1742-4755 $-3-2$

Wau, H., \& Razella, N. (2020). Utilization of Antenatal Care (ANC) Services by Pregnant Women in Binjai City and Factors Affecting. Jurnal Kesehatan Masyarakat, 15(3), 390398. Retrieved from https://dx.doi.org/10.15294/kemas.v15i3.20613 10.15294/ kemas.v15i3.20613 